\title{
An Exploration of Factors Contributing to the Perceptions of Preparedness for Elementary Candidates in a Clinically Based Program
}

\author{
Rebecca McMahon Giles ${ }^{1}$ and Andrea M. Kent ${ }^{2}$ \\ ${ }^{1}$ Department of Leadership and Teacher Education, College of Education, University of South Alabama, \\ UCOM 3100, Mobile, AL 36688-0002, USA \\ ${ }^{2}$ College of Education, University of South Alabama, UCOM 3606, Mobile, AL 36688-0002, USA \\ Correspondence should be addressed to Rebecca McMahon Giles; rgiles@southalabama.edu
}

Received 6 November 2013; Accepted 19 December 2013; Published 9 January 2014

Academic Editors: M. J. Cabral dos Santos Reis and K. Capps

Copyright (C) 2014 R. M. Giles and A. M. Kent. This is an open access article distributed under the Creative Commons Attribution License, which permits unrestricted use, distribution, and reproduction in any medium, provided the original work is properly cited.

A quantitative, descriptive research model was used to investigate the perceptions of teacher candidates $(n=32)$ in a clinically based dual certification program regarding their culminating student teaching experience. Data consisted of candidates' responses to both multiple choice and open ended survey items. Results indicated that teacher candidates within an undergraduate program leading to state teaching certification in both elementary and collaborative teaching (K-6) had positive perceptions regarding their preparedness as a result of prior experiences working in K-6 classrooms (44\%) and interactions with in-service teachers (28\%). In addition, teacher candidates perceived strong relationships with their university supervisors reporting that they received a greater amount of encouragement and feedback for improved teaching from their university supervisors than from their cooperating teachers.

\section{Introduction}

Clinical supervision has been well covered in scholarly literature [1-7]. According to Glickman [4], clinical supervision is the "best known, oldest, and most widely used structure for working directly with classroom teachers." Cogan [2] distinguishes between general supervision, which takes place mainly outside the classroom (i.e., writing and revising lessons, preparing instructional materials, etc.) and clinical supervision, which focuses on using actual classroom events to improve classroom instruction. Research on professional development schools and urban teacher residencies indicates that new teachers prepared in these intensive clinically based programs have greater teacher efficacy and higher retention rates [8]. Similarly, Carriveau [9] found that candidates in an elementary education, one-year residency program rated themselves significantly higher in teacher efficacy than secondary education candidates who completed a more traditional one-semester internship model.
In the last decade, substantial reports indicate that large numbers of teachers choose to leave the profession early in their careers [10-13]. Though there may be many reasons for teacher attrition, the shortcomings of a traditional teacher preparation program have been cited as contributing to the continuous teacher turnover currently plaguing the profession $[14,15]$. Specifically, the separation of theory and practice throughout traditional teacher preparation programs has been cited as one area of concern. Keiny [16] stated that "teachers' education should emphasize understanding not merely on the theoretical level, but as an integration of theory and action." The answer may lie in using deep, rich field experiences to integrate the empirically-based pedagogy of teacher education courses with practically oriented application in order to graduate successful teachers committed to staying in the profession [17]. The task of better preparing new teachers takes a concerted effort by colleges of education to adequately consider current teaching challenges and, in response, create programs that suitably stimulate the transfer 
of a university-obtained knowledge base to a classroom setting [18].

One university in the southeast United States creatively restructured its undergraduate teacher preparation programs in order to merge elementary and special education into a single program. These changes came in timely response to the intensifying demand for teachers who are prepared to work in inclusive classrooms. The K-6 Teacher Education program leads to dual certification in elementary and collaborative teaching (K-6) without increasing either the length of time or number of credit hours required for degree completion. To accomplish this, the curriculum was restructured to include both special education and general education standards in all courses. In addition to redesigning coursework, field experiences changed dramatically.

Critical to the new program were increased expectations regarding field requirements in both duration and application of content. Historically, field experiences have not been considered a priority in many teacher preparation programs [19], tending to be sporadic and brief. Further, these experiences often lack specificities and reflective opportunities that guide candidates in what they are to be learning while also failing to make an adequate connection to other components of the program $[20,21]$. In contrast, the K-6 Teacher Education program became a clinically based program combining coursework in general and special education with extensive field experiences totaling nearly 1,000 clock hours in a partner school over three consecutive semesters. Table 1 presents an overview of the program's courses and field experience requirements.

Eighteen partner elementary schools in two local districts were identified through a joint selection process involving university and public school personnel. Criteria for selection included strong principal leadership as evidenced by teacher commitment, academic achievement, and a positive school climate; a commitment to life-long learning; and a willingness to invest the time and effort in the preparation and mentoring of future teachers.

A university field experience supervisor was assigned to each participating school. Every field experience supervisor was a university faculty member designated to serve as liaison between the school and university while assuming responsibility for the supervision of all candidates within the school, regardless of the candidates' placement in the program. As a result, the traditional role of the university supervisor changed significantly to embrace a model of tiered supervision. The supervisors routinely adopted the role of mentor, coach, and evaluator as they regularly conducted the following activities: (1) conferenced with, observed, and evaluated candidates; (2) engaged in model teaching; (3) collaborated with the cooperating teachers, and (4) communicated with the school administration to ensure that the needs of the candidates, cooperating teachers, and elementary students were being met. Through their consistent presence, supervisors established secure, long-term relationships with both school personnel and candidates becoming a known commodity at the school.

According to Küster et al. [22], preservice teachers must experience a wide range of learning opportunities during
TABLE 1: Overview of the K-6 teacher education program.

\begin{tabular}{|c|c|c|}
\hline & Courses & $\begin{array}{c}\text { Field } \\
\text { experience }\end{array}$ \\
\hline $\begin{array}{l}\text { Tier } 1 \text { (18 hours) } \\
\text { precandidacy }\end{array}$ & $\begin{array}{l}\text { Microcomputing Systems in } \\
\text { Education } \\
\text { Education in a Diverse Society } \\
\text { Human Growth and } \\
\text { Development } \\
\text { Evaluation of Teach and } \\
\text { Learning } \\
\text { Health and Movement } \\
\text { Education } \\
\text { Arts in the Elementary } \\
\text { Classroom }\end{array}$ & 20 hours \\
\hline $\begin{array}{l}\text { Tier } 2 \text { ( } 17 \text { hours) } \\
\text { introductory } \\
\text { methods }\end{array}$ & $\begin{array}{l}\text { K-6 Education } \\
\text { Foundations of Reading } \\
\text { Instruction } \\
\text { Teaching Social Studies } \\
\text { Learning and Behavioral } \\
\text { Disorders } \\
\text { Behavioral Management } \\
\text { Classroom Management } 1 \text { (1 hr.) } \\
\text { Field Experience }(1 \mathrm{cr} . \mathrm{hr} .)\end{array}$ & 200 hours \\
\hline $\begin{array}{l}\text { Tier } 3 \text { (17 hours) } \\
\text { advanced methods }\end{array}$ & $\begin{array}{l}\text { Teaching Mathematics } \\
\text { Teaching Science } \\
\text { Teaching Reading } \\
\text { Partnerships in Special } \\
\text { Education } \\
\text { Intellectual and Physical } \\
\text { Disabilities } \\
\text { Classroom Management } 2 \\
\text { (1 hr.) } \\
\text { Field Experience (1 hr.) }\end{array}$ & 250 hours \\
\hline $\begin{array}{l}\text { Tier } 4 \text { (12 hours) } \\
\text { internship }\end{array}$ & $\begin{array}{l}\text { Student Teaching EEC ( } 6 \text { hrs.) } \\
\text { Student Teaching Collaborative } \\
\text { K-6 ( } 6 \text { hrs.) }\end{array}$ & 525 hours \\
\hline
\end{tabular}

their preparation program to avoid feeling underprepared when they begin teaching. The purpose of this study was to examine the perceptions of K-6 Teacher Education candidates' in a clinically based, dual certification program regarding perceptions of their overall preparedness for student teaching in elementary classrooms. Specifically, the research questions for this study were as follows.

(1) What are candidates' perceptions regarding their overall preparedness for student teaching and the specific factors that contributed to their being prepared?

(2) What are candidates' perceptions regarding their relationships with their cooperating teachers and university supervisors?

\section{Materials and Methods}

The study was quantitative and descriptive, and survey method was applied to collect data.

The data of the study was gathered through an anonymous, 20-item electronic survey routinely distributed to all teacher education candidates upon completion of their 
TABLE 2: Candidates' perception of their relationship with cooperating teacher.

\begin{tabular}{lccccc}
\hline & \multicolumn{2}{c}{ My cooperating teacher's relationship with me: } & & \\
& Strongly agree & Agree & Somewhat agree & Disagree & Strongly disagree \\
\hline $\begin{array}{l}\text { Demonstrated commitment to my } \\
\text { well-being and development }\end{array}$ & $64.5 \%(20)$ & $25.8 \%(8)$ & $6.5 \%(1)$ & $3.2 \%(1)$ & $0.0 \%(0)$ \\
$\begin{array}{l}\text { Treated me fairly and with respect } \\
\text { Encouraged me }\end{array}$ & $67.7 \%(21)$ & $22.6 \%(7)$ & $9.7 \%(3)$ & $0.0 \%(0)$ & $0.0 \%(0)$ \\
$\begin{array}{l}\text { Met with me routinely to help me plan } \\
\text { Provided feedback that helped improve }\end{array}$ & $64.5 \%(20)$ & $22.6 \%(7)$ & $9.7 \%(3)$ & $3.2 \%(1)$ & $0.0 \%(0)$ \\
my teaching & $61.0 \%(22)$ & $25.8 \%(8)$ & $0.0 \%(0)$ & $3.2 \%(1)$ & $0.0 \%(0)$ \\
\hline
\end{tabular}

program as a means of obtaining general feedback about their student teaching experience. The data for this study came from responses to one open ended question and 3 multiple choice items. The open ended question asked, "Did you feel prepared for your overall student teaching experience? Specifically, what contributed to your feeling of being prepared?" Two of the multiple choice items asked candidates to rate 5 separate aspects of their relationship with their cooperating teacher and university supervisor using a 5 point Likert-like response scale ranging from Strongly Agree to Strongly Disagree. The final item asked candidates to report the number of classroom visits made by their university supervisor.

The participants were K-6 Teacher Education majors $(n=$ 32) completing a program leading to a Bachelor of Science degree and dual certification in elementary and collaborative teaching who were student teaching during a single semester. To maintain complete anonymity, no demographic information was collected for participants. Descriptive statistics in the form of percentages were calculated for the participants' responses.

\section{Results}

Thirty-two participants responded to the question "Did you feel prepared for your overall student teaching experience? Specifically, what contributed to your feeling of being prepared?" Thirty-one (97\%) reported feeling prepared for their overall student teaching experience while a single candidate reported feeling unprepared. Fourteen candidates (44\%) listed prior experiences working with K-6 children in a classroom setting as having contributed to their feelings of preparedness. Of these, five candidates specifically mentioned required field experiences while four identified their voluntary participation in a university-sponsored summer enrichment program for elementary children. Nine candidates $(28 \%)$ cited prior interactions with in-service teachers through both university-based and personal experiences as beneficial. Three candidates acknowledged the contributions of their cooperating teacher and/or the faculty at their placement school while one candidate named the university supervisor as having contributed to her sense of preparedness.

Participants $(n=32)$ also rated aspects of their relationship with their cooperating teachers and university supervisors. The results of these ratings are presented in Table 2. Regarding their relationship with their cooperating teachers, 22 candidates $(71.0 \%)$ strongly agreed that their cooperating teachers met with them routinely to assist in planning while 19 (61.3\%) strongly agreed that their cooperating teachers provided feedback that was beneficial to improving their teaching. Twenty-one candidates $(67.7 \%)$ strongly agreed that they were treated fairly and with respect by their cooperating teachers.

The results of the ratings regarding candidates' relationship with their university supervisors are presented in Table 3. Twenty-one candidates (67.7\%) strongly agreed that they were encouraged by their supervisors and that supervisors provided feedback to help improve their teaching. Only 17 (54.8\%) strongly agreed that they met routinely with their university supervisors to receive planning assistance. All 32 candidates (100\%) agreed, at least somewhat, that they were treated fairly and with respect by their university supervisors and that their university supervisors demonstrated commitment to their well-being and development.

Candidates reported the number of university supervisors' visits to the classrooms during the fifteen-week student teaching semester as follows: 6 candidates (19.4\%) were visited 3 or 4 times and 25 candidates $(80.6 \%)$ were visited 5 or more times.

\section{Discussion}

Almost all candidates (31 out of 32) expressed feelings of overall preparedness for student teaching. Candidates specifically cited interactions with in-service teachers as the most influential factor in contributing to their preparedness. Although two candidates mentioned that these interactions occurred with family or friends who were teachers, the vast majority of connections to elementary classroom teachers occurred as a result of required program field experiences. In addition, five candidates specifically identified prior field experiences as contributing to their feelings of being prepared during student teaching. Other candidates made general statements like "The last semester was a great learning experience" and "The time spent in Tier 2 and Tier 3 was a big help." Since the two semesters prior to student teaching, commonly known within the program as Tier 2 and Tier 3, contained significant field experiences courses, it is assumed that such broad statements were intended to include field 
TABLE 3: Candidates' perception of their relationship with university supervisor.

\begin{tabular}{|c|c|c|c|c|c|}
\hline \multicolumn{6}{|c|}{ My university supervisor's relationship with me: } \\
\hline & Strongly agree & Agree & Somewhat agree & Disagree & Strongly disagree \\
\hline Demonstrated commitment to my well-being and development & $61.3 \%(19)$ & $25.8 \%(8)$ & $12.9 \%(4)$ & $0.0 \%(0)$ & $0.0 \%(0)$ \\
\hline Treated me fairly and with respect & $64.5 \%(20)$ & $22.6 \%(7)$ & $6.5 \%(2)$ & $0.0 \%(0)$ & $0.0 \%(0)$ \\
\hline Encouraged me & $67.7 \%(21)$ & $22.6 \%(7)$ & $6.5 \%(2)$ & $3.2 \%(1)$ & $0.0 \%(0)$ \\
\hline Met with me routinely to help me plan & $54.8 \%(17)$ & $25.8 \%(8)$ & $12.9 \%(4)$ & $3.2 \%(2)$ & $3.2 \%(1)$ \\
\hline Provided feedback that helped improve my teaching & $67.7 \%(21)$ & $19.4 \%(6)$ & $9.7 \%(3)$ & $0.0 \%(1)$ & $3.2 \%(0)$ \\
\hline
\end{tabular}

experiences as well as coursework. Further, three candidates referenced their courses in general. Each of the prior field experiences was an actual course and may have been included in these references as well. In the words of one candidate, "I felt very prepared for my student teaching experience. I feel that having two semesters in the school prior to student teaching played the biggest factor in me being prepared because it provided me hands-on experience. I learned and improved classroom management skills, practiced teaching lessons, and had great mentor teachers to learn from."

An examination of the data revealed that the majority of candidates perceived having positive relationships with both their cooperating teachers and university supervisors. Not surprisingly, candidates indicated that more time was spent planning with the cooperating teacher rather than the university supervisor. Interestingly, candidates perceived their university supervisors as being more encouraging and as having a greater impact on improving their teaching through constructive feedback than their cooperating teachers. These findings support previous research [23, 24], noting that university supervisors appear to provide emotional support needed for candidates to acclimate to the initial hurdles encountered in student teaching. This may be particularly true for candidates in this study who had an established relationship with their university supervisor when student teaching began while only having just met their cooperating teachers. The positive impact of a prior relationship between university supervisors and student teachers was also found by Asplin and Marks [25] who reported a significantly greater influence by university-based supervisors on candidates' teaching practices when they had taken a class with the supervisor prior to student teaching. Specifically, Asplin and Marks found that a previous working relationship led to student teachers viewing their supervisors as more knowledgeable and made them more willing to take and apply advice given by their university supervisor well as an increased positive personal relationship with the supervisor. These findings led them to conclude that some type of faculty consistency in a program that builds rapport is beneficial for student teachers. While university instructors and cooperating teachers changed as candidates progressed through the K-6 Teacher Education program, the university supervisor remained a constant, consistent ally throughout the program and was a vital aspect of all previous experiences.

The vast majority of candidates $(80.6 \%)$ reported that they received 5 or more classroom visits from their university supervisor during their student teaching semester. Candidates' face-to-face interactions were assuredly greater with their cooperating teachers, with whom they shared a daily working schedule (at least 7 hours a day 5 days a week for 16 weeks). Since increased time spent together offers more time for collaboration in planning and preparing for instruction, it is logical that candidates would report more planning time with cooperating teachers than university supervisors. A greater number of contact hours would also provide more time for the cooperating teachers to observe the candidate's teaching and engage in discussion and joint reflection of the candidate's teaching. However, candidates ranked university supervisors higher in terms of providing feedback for improving teaching.

It is assumed that contact among candidates and university supervisors was maintained between visits through various forms of communications (i.e., email messages, texts, phone calls, etc.) and on-campus meetings. Including longdistance interactions, total time of engagement between candidates and university supervisors had to be less than that of candidates and cooperating teachers, thus leading to the inference that the less quantity of interactions between candidates and university supervisors was of a higher quality and, as a result, perceived as more encouraging and meaningful in regard to improved teaching.

Whether working with students or teacher candidates, no one approach works for all $[26,27]$. Rather, a variety of instructional strategies and approaches must be employed based on the needs of the learner. Deeper knowledge of the candidate's skills and abilities as a result of an established working relationship over three consecutive semesters may have better equipped university supervisors to make adjustments based on individual need.

4.1. Limitations. As in all studies, there are some limitations that should be acknowledged. In this study, participants were a convenience sample of elementary teacher candidates completing the program in a single semester. Therefore, the results of this study may not be generalizable to all teacher education programs. Further, the means of data collection was a survey, and the self-reporting nature of surveys is a limitation in that what survey respondents perceive to be true may not actually be true, thus inadvertently leading to misrepresentation.

4.2. Further Research. Though research supports that quality field experiences play a critical role in learning to teach [28], Anders et al. [29] caution that there is little research available 
in the literature that describes the actual components of effective field experiences. Likewise, this research did not identify specific field elements, such as the quality of feedback or the amount of time spent engaging in reflective conversation, that teacher candidates perceived to be beneficial to their preparedness for student teaching. More specifically, research on the perceived positive characteristics of the relationships of both university supervisors with candidates and classroom teachers with candidates should be examined. In addition, future research should be conducted to specifically examine candidates' perceptions of the university courses, prior field experiences, and the supervisors' role on their sense of preparedness to be successful in student teaching.

\section{Conclusions}

Learning to teach is a multifaceted, complex effort $[10,20$, 30,31 . Findings suggest that the relationship between teacher candidates and their university field supervisors facilitates the transfer of learning from the university to the elementary classroom during student teaching. Encouraging reflection, providing guidance through coaching, and facilitating reflection through conversations are scaffolds that assist new teachers along their journey to become reflective practitioners of their craft [32]. The role of a supervisor should extend beyond providing guidance on a specific lesson or unit but rather the supervisor must be an essential element in the growth and development of preservice teachers across all domains of teaching [33]. Unfortunately, the role and influence of the university supervisor within the student teaching process are frequently ignored or discounted [24]. Because research suggests that the quality of teacher preparation programs impacts teaching practice and student achievement [34], no aspect of teacher preparation can be ignored, least of all the position of university field supervisor.

\section{Conflict of Interests}

The authors declare that there is no conflict of interests regarding the publication of this paper.

\section{References}

[1] J. M. Aseltine, J. O. Faryniarz, and A. J. Rigazio-DiGilio, Supervision for Learning, Association for Supervision and Curriculum Development, Alexandria, VA, USA, 2006.

[2] M. Cogan, Clinical Supervision, Houghton-Mifflin, Boston, Mass, USA, 1973.

[3] A. Glatthorn, Differentiated Supervision, Association for Supervision and Curriculum Development, Alexandria, VA, USA, 1984.

[4] C. D. Glickman, Leadership for Learning: How to Help Teachers Succeed, Association for Supervision and Curriculum Development, Alexandria, VA, USA, 2002.

[5] T. A. Micek, "Critique of clinical supervision: initial feedback," The Field Experience Journal, vol. 9, pp. 79-94, 2011.

[6] P. F. Oliva, Supervision for Today's Schools, Longman, New York, NY, USA, 4th edition, 1993.
[7] E. Pajak, Honoring Diverse Teaching Styles: A Guide for Supervisors, Association for Supervision and Curriculum Development, Alexandria, VA, USA, 2003.

[8] Council of Chief State School Officers, Our Responsibility, Our Promise: Transforming Educator Preparation and Entry into the Profession, Washington, DC, USA, 2012.

[9] R. Carriveau, "Impacts of a one-year residency program on student teachers' teacher efficacy beliefs," The Field Experience Journal, vol. 9, pp. 59-78, 2012.

[10] L. Darling-Hammond and G. Sykes, "Wanted: a national teacher supply policy for education: the right way to meet the "highly qualified teacher" challenge," Education Policy Analysis Archives, vol. 11, no. 33, 2003.

[11] D. Hare and J. L. Heap, Effective Teacher Recruitment and Retention Strategies in the Midwest: Who Is Making Use of Them? North Central Regional Educational Lab, Naperville, Ill, USA, 2001.

[12] H. R. Johnson, "Administrators and mentors: keys in the success of beginning teachers," Journal of Instructional Psychology, vol. 28, no. 1, pp. 44-49, 2001.

[13] C. Pipho, "A "real" teacher shortage," Phi Delta Kappan, vol. 80, no. 3, pp. 181-182, 1998.

[14] M. Haberman, "Raising teachers' salaries: the funds are there," Education, vol. 125, no. 3, pp. 327-343, 2005.

[15] A. M. Kent, P. Feldman, and R. L. Hayes, "Mentoring and inducting new teachers into the profession: an innovative approach," International Journal of Applied Educational Studies, vol. 5, no. 1, pp. 73-95, 2009.

[16] S. Keiny, "Constructivism and teachers' professional development," Teaching and Teacher Education, vol. 10, no. 2, pp. 157167, 1994.

[17] F. Korthagen, J. Loughran, and T. Russell, "Developing fundamental principles for teacher education programs and practices," Teaching and Teacher Education, vol. 22, no. 8, pp. 10201041, 2006.

[18] F. A. J. Korthagen and J. P. A. M. Kessels, "Linking theory and practice: changing the pedagogy of teacher education," Educational Researcher, vol. 28, no. 4, pp. 4-17, 1999.

[19] R. A. Wiggins, E. J. Follo, and M. B. Eberly, "The impact of a field immersion program on pre-service teachers' attitudes toward teaching in culturally diverse classrooms," Teaching and Teacher Education, vol. 23, no. 5, pp. 653-663, 2007.

[20] S. Feiman-Nemser, "From preparation to practice: designing a continuum to strengthen and sustain teaching," Teachers College Record, vol. 103, no. 6, pp. 1013-1055, 2001.

[21] A. M. Villegas and T. Lucas, "Preparing culturally responsive teachers rethinking the curriculum," Journal of Teacher Education, vol. 53, no. 1, pp. 20-32, 2002.

[22] D. Küster, C. Bain, M. Milbrandt, and C. Newton, "Novice art teachers: navigating through the first year," Visual Arts Research, vol. 36, pp. 22-30, 2010.

[23] S. Caires, L. Almeida, and C. Martins, "The socioemotional experiences of student teachers during practicum: a case of reality shock?" Journal of Educational Research, vol. 103, no. 1, pp. 17-27, 2009.

[24] M. J. Marks, From coursework to classroom: a qualitative study on the influences of preservice teacher socialization [doctoral dissertation], University of Cincinnati, Cincinnati, Ohio, USA, 2002.

[25] K. N. Asplin and M. J. Marks, "Increasing the influence of university supervisors during student teaching," Professional Educator, vol. 37, no. 1, pp. 1-10, 2013. 
[26] C. D. Glickman, Developmental Supervision: Alternative Practices for Helping Teachers Improve Instruction, Association for Supervision and Curriculum Development, Alexandria, VA, USA, 1981.

[27] S. Stotsky, "Who should be accountable for what beginning teachers need to know?" Journal of Teacher Education, vol. 57, no. 3, pp. 256-268, 2006.

[28] B. Maloch, J. Fine, and A. S. Flint, "I just feel like I'm ready:'exploring the influence of quality teacher preparation on beginning teachers," The Reading Teacher, vol. 56, pp. 348-350, 2003.

[29] P. L. Anders, J. V. Hoffman, and G. G. Duffy, "Teaching teachers to teach reading: paradigmshifts, persistent problems, and challenges," in Handbook of Reading Research, M. Kamil, P. Masenthal, P. D. Pearson, and R. Barr, Eds., vol. 3, pp. 719-744, Lawrence Erlbaum Associates, Mahwah, NJ, USA, 3rd edition, 2000.

[30] D. C. Berliner, "Learning about and learning from expert teachers," International Journal of Educational Research, vol. 35, no. 5, pp. 463-482, 2001.

[31] H. Borko and R. Putnam, "Learning to teach," in Handbook of Educational Psychology, D. Berliner and R. Calfee, Eds., MacMillan, New York, NY, USA, 1996.

[32] L. A. Daloz, in Mentor: Guiding the Journey of Adult Learners, Jossey-Bass, San Francisco, Calif, USA, 1999.

[33] C. F. Danielson, Enhancing Professional Practice: A Framework for Teaching, Association for Supervision and Curriculum Development, Alexandria, VA, USA, 1996.

[34] L. Darling-Hammond, "Teacher quality and student achievement: a review of state policy evidence," Education Policy Analysis Archives, vol. 8, p. 1, 2000. 